\title{
Rethinking Why and How China Wins Hearts and Minds in Africa
}

\author{
Isaac Olawale Albert
}

\begin{abstract}
China is today the biggest development partner to Africa. To reduce the country's growing influence in the continent, the western media is saturated with negative reports on how the people do business. The Chinese are said to be pursuing imperialist agenda and striking economic and political deals with corrupt and rogue regimes in Africa. This is believed to have corrosive effects on the growth of democratic governance in the continent. These criticisms notwithstanding, the influence of China in Africa has continued to grow. This paper tries to explain the paradoxical situation. African regimes work with the Chinese because the latter treat them with respect and tie no political conditionality to the support given to them. The Chinese also provideAfrican political leaders with infrastructural support under liberal terms. The grassroots African peoples are also favourably disposed towards the Chinese because of their pro-poor policies and stances. They provide Africans with affordable phones and household appliances; they build roads, live amongst the people and work as equals with them at construction sites. The paper concluded on the note that the western criticism of China in Africa is more in the interest of the developed world than Africa. The western world is advised to treat Africans with better respect if it wants to enjoy the kind of influence that the Chinese are now having in Africa.
\end{abstract}

\section{Introduction}

China considers Africa a vital component of its growth strategy in terms of access to natural resources, energy and market for manufactured products. Within this framework, its investment in the continent is now greater than that of any other foreign power. The Chinese claim to be in Africa to teach selfdevelopment to Africans and by so doing free the people from being pliant subjects of the western world that endlessly feeds them with aids rather than trade.

On the other hand, the western world criticizes China's relations with Africa as being exploitative, extractive, conducive to corruption, and insensitive to the protection of human rights in Africa. The increasing rate at which the Chinese penetrate different parts of Africa suggests that Africans do not consider them to be as bad as presented by the western media. The goal of this paper is to take a critical look at the reasons for this widespread tolerance of the Chinese in Africa. Why and how do the Chinese win so many hearts and minds in Africa? 
Indeed, a lot has been published on China's relations with Africa in recent year, as can be seen from the array of literature drawn upon in this paper. One of the most critical issues raised in the emerging discourse is that China is today a major force in African development. The country shows good signs of deeper penetration into Africa in the future. The number of African states having a relationship with China in 1986 was just six. This figure increased to 35 in 2006, with the most prominent countries being those with rich natural resources. By the same year, during which the 2006 Beijing summit of the Forum on China-Africa Cooperation (FOCAC) was held, Africa's trade with China rose to $\$ 50$ billion from the $\$ 1$ billion mark reached in $1986 .{ }^{1}$ Sino-African relations have deepened significantly thereafter. By 2012, Chinese companies dominated the African construction sector, with a market share larger than those of France, Italy and US combined despite the downturn in the global construction market resulting from the emerging global economic crisis. ${ }^{2}$ By 2012, China's trade with Africa had reached $\$ 180 \mathrm{bn}$ mark and the growth continues by leaps and bounds. ${ }^{3}$

Sino-African trade partnership in the 2000s focused on four issues. First and foremost, Beijing funded infrastructure projects across the continent, most especially in places where such international support had stopped coming from the World Bank and other bilateral donors. Second, China prioritized working with the African Development Bank rather than the World Bank or the larger international financial institutions for the acceleration of African development. Third, the Chinese invested heavily in the training of African professionals, most especially in the field of economic management. This objective was achieved through the establishment of an African Human Resources Development Fund which still trains and retrains about 3,800 African professionals annually. Last but not the least, China established cooperation agreements with 27 African universities through which Chinese language would be taught under the auspices of China's Confucius Institute Project.

However, the western media has placed on the front-burner reportage of the seamy side of the Chinese engagement in Africa. China is criticised for doing business withAfrican regimes denounced by the international community for violating the fundamental rights of their citizens. ${ }^{4}$ The African countries with which China has this kind of condemned relationship include Sudan, Guinea, Zimbabwe, Angola and a few others. China does not only do business with these countries but also protects them from agencies and organs of the international community that try to isolate or sanction them. For example, China started to invest heavily in oil extraction in Sudan in 1996 to fill the vacuum created by some western oil firms that scaled down their investment in the country on account of the unhealthy human rights records of President Omar Hassan al-Bashir. This was to the extent that by 2006, $10 \%$ of China's oil import was from Sudan; $15 \%$ came from Angola.

While the presence of China in Sudan strengthened the regime of Bashir and made him more recalcitrant in dealing with the international community, the oil imports from Angola frustrated the attempt by the International Monetary Fund (IMF) to include transparency measures in the loan that the country had wanted to take from it. China encouraged Angola to treat the IMF with disdain by granting it a loan of $\$ 2$ billion at a favourable rate not even tied to any conditionally beyond oil supply and construction contracts. ${ }^{5}$ The situation in Guinea was equally implicative. As the global community condemned the military junta in the country not only for returning military rule to the West African sub-region but more importantly for its recent crackdown on opposition protesters, it was announced in October 
2009 that China International Fund, a major Chinese investor in Angola, was in talks to forge a $\$ 7$ billion mining deal in Guinea.

The point made above is that the Chinese pursue political and economic objectives opposed to the interest of the big western powers. ${ }^{6}$ Whereas the traditional trading partners of Africa used both political and economic diplomacy to force African leaders to work in the best interest of their people, China pursues a policy of "non-interference" that allows African leaders with relationships with the Chinese to conduct themselves as they wish. During a visit to Nigeria, David Cameron, the British Prime Minister, described this kind of relationship with Africa as 'authoritarian capitalism'. He warned Africa against it, arguing that it is unsustainable in the long term. ${ }^{7}$ Another accusation against China is that it is pursuing a colonial agenda in Africa. ${ }^{8}$

It is interesting to note that the Chinese are not seriously deterred by any of these criticisms. They carry on their businesses in Africa as if nobody is talking about them. Interestingly, African leaders and peoples are equally not much worried by the criticisms and their dispositions are captured by two popular Yoruba adages. The first says "The noise in a marketplace does not wreck it" and the second says "In the noisy marketplace it is advisable to face one's business partner". Hence, the relationship between China and the African peoples continue to wax stronger. This is surprising to western observers. How have the Chinese been able to win so many hearts and minds in Africa? That is the main question to be answered by this paper.

\section{Winning Hearts and Minds}

Many African leaders do business with the Chinese on account of some unhealthy treatments they have experienced in the hands of western powers. It is common for these African leaders to go to the western powers for loans and aids. The developed world often ties harsh political conditionalities to the financial support it grants African leaders. The most common of the conditions is for the African leaders to fulfil some pro-democracy and human rights obligations. Many African leaders are not happy with this kind of situation that makes the western world closely monitor how they govern their people. What the Chinese smartly did is to tap into this conflict situation between African leaders and the developed world. They did two things in this respect. Through their policy of "non-interference" they left African leaders with human rights problems to find solutions to them on their own rather than by imposing any solutions on them. Rather, the Chinese focus their attention on trade and the provision of infrastructure for Africa in a manner that shores up the legitimacy of some of the African political leaders. This step has endeared many African leaders to the Chinese.

Some people also believe that the human rights claims of the western world for Africa are not born of sincerity. In this context, it is argued that the way the Chinese pursue their economic interests is not totally different from how other countries pursue theirs. For example, Professor David C. Kang of Dartmouth College argues that "We (the Western World) support Pakistan, Egypt, Saudi Arabia - huge human rights violators - because we have other strategic interests. China's not unique in cutting deals with bad governments." "black". In 2013, President Jacob 
Zuma had to warn western companies to stop the admonition against the embrace of China. According to him, "China is doing business in a particular way and we think we can see the benefits.... But we are very, very careful." He cited how Africa managed colonialism in the past to show that the continent is, not totally ignorant of how to manage a colonial power should China turn out to be one. ${ }^{10}$

Development is more about how the peasants and working class feel than how political leaders feel. It is unfortunate that the economic models of the western world hardly touch the grassroots people who indeed are the ultimate beneficiaries of the presence of the Chinese in Africa. This claim is not only about Africa; rather it applies to many other parts of the world as well. Anumber of publications call attention to this problem. One of them is Paul Collier's The Bottom Billion: Why the Poorest Countries Are Failing and What Can Be Done About $-\mathrm{ft} .{ }^{11}$ Collier discusses what he calls the "headless heart" syndrome - referring to the tendency of people in rich countries to approach Africa's problems with more emotion than empirical evidence.

Those needing assistance in Africa are the poor that have long been abandoned by their leaders. On the other hand, the development model of the developed world do more in the direction of further empowering the rich rather than the poor. In the past, the people merely heard about development, but things are changing now to the extent that they now feel development when it happens. Commenting on this, Joseph Mucheru, Google's regional lead for sub-Saharan Africa, observed that "Unless you are in Africa, you may not appreciate the continent.... Unfortunately, images of pain, war, famine and corruption dominate international media coverage of the continent, masking the true story of what is happening in the region.... We have seen growth and we are expecting more." 12

The Chinese contribute significantly to the kind of change that Mucheru was talking about. He was specifically referring to the changes brought about by the social media. To many Africans, the Chinese make it possible for them to be able to own a phone. Commenting on how the telephone opened up Africa, the African Defence Forum observed that "In the first decade of the new millennium, African telecommunication companies gained 316 million mobile phone subscribers. That total is greater than the entire US population."13

Most of these telephone users are in Nigeria and most of these Nigerians use Chinese phones because of their affordability. In the subscriber data released by the Nigerian Communication Commission in January 2014, the active telephone lines in the country increased from 121.2 million in September 2013 to 121.8 million at the end of October, 2013, representing a growth of over 600,000 new active lines added on the networks. ${ }^{14}$ This growth rate is not because Nigerians were getting richer but because of higher access to cheaper phones. In many parts of Nigeria and indeed the African continent, the grassroots people use their cheap Chinese phones to pass security information to security agencies though the same phones are used by insurgents and terrorists to organise their activities. In other words, both "good" and "bad" Africans are grateful to the Chinese for their phones.

The Chinese are not only interested in Africans having cheap phones, they put in place mechanisms that ensure that once these people buy a phone they keep it for a long time. Many Nigerian phone sellers also repair and sell parts of Chinese and other conventional 
phones. In April 2014,1 spoke to traders dealing in Chinese phones at both Wuse II market and the GSM market in Abuja and it was realised that indeed we have more people involved in the business of Chinese phone accessories than in the selling of these phones.

The accessories dealers sell materials needed by those using the mainstream phones as well as those selling Chinese phones. What they offer for sale range from the back cover of phones to batteries, chips, screens, and the minutest spare parts of phones. Therefore, instead of buying new phones, people just take their old ones to the repairers and they are turned to "second new". That is an excellent coping strategy that the western phone companies do not provide for, and this explains why the poor in Africa move increasingly toward the Chinese.

Chinese products that are helping to ease the hardship of life for the poor in Africa include cheap washing machines that can be purchased with as little as $\$ 100$; rechargeable lamps costing less than $\$ 5$ that now enable students to read at night when and where there is no stable electricity in their communities; and rechargeable standing fans that do not only cool rooms but drive away mosquitoes at night. There are several other Chinese products across Africa that the grassroots people have now become used to. Users of such products would not want to be persuaded that the Chinese are bad.

One other area in which the grassroots people in Africa are beginning to appreciate the Chinese is how they are now involved in providing physical infrastructure such as roads, public buildings, airports and the like. As they do this, the Chinese use what the western world criticises as "direct labour". In other words, the Chinese make citizens of their countries do some of the menial jobs that the local people could do.

The local people do not see this as the Chinese taking away local jobs. Local interpretation of this is that the Chinese are humble and not as arrogant as the western contractors they worked with in the past. The Chinese remove their clothes and participate in whatever they ask the local people to do. They carry blocks, mix cement and participate in fixing the blocks. They drink the same water as the local people and eat the same food as them. Some of the Chinese sleep on project sites without any luxuries. They deliberately make the local people see them as equals. If allowed, the Chinese signal the readiness to live among the people.

\section{Towards a Deeper Explanation}

The epistemological shock that this paper is contending with is the fact that despite the harsh criticism of how the Chinese do business in Africa, both African governments and peoples are shifting away from their traditional dependence on the western powers to create new relationships with the Chinese. We need to shed deeper light on this issue. Like the Africans, China hardly responds to the accusations against it in the western media. Most times, it continues its business in Africa as ifnothing is happening, thus seeming to apply the wisdom of that popular Yoruba adage alluded to earlier: "Don't be distracted by the noise in the marketplace; just face your customer". But on a few occasions, the Chinese have been forced to respond. One such opportunity was provided in June 2013 when the 
Chinese Peoples Association for Peace and Disarmament (CPAPD) brought to Beijing several journalists and NGO leaders from Botswana, South Africa, Ethiopia, Uganda, Tanzania, Kenya, Zambia and Zimbabwe for a meeting centred on China-Africa relations. The Counsellor in the African Department at the Ministry of Foreign Affairs in China, Lin Jing, observed, while addressing the gathering, that China was not only interested in benefiting economically from Africa but wanted the continent to better the living standards of its people. He argued that China had a "soft spot" for Africa and its relationship with Africa was not predatory as alleged. According to him, "We can not only think of the economic side of the relationship.

Our relationship is that of moral obligation and we need to support each other so that we can have a better world." 15 He said even at the time the Chinese economy was experiencing deep crisis, China still helped Zambia and Tanzania construct the Tanzania Zambia Railway Line (TAZARA), a gesture showing that the country was committed to assisting African people. He observed that the main focus of his country was to ensure that its support to Africa reached people at the grassroots so that poverty could be reduced. He would want Africa to be China's best ally as the two peoples strove to develop themselves in the contemporary world.

Chima Theke too has observed that no amount of criticism would stop Africans from following the Chinese. He argued that the Chinese would always win the hearts and minds of African peoples so long as western powers treat Africans with disrespect. His arguments are captured by a Yoruba adage which says that "Children do not run in the direction of bullies but those offering bean cakes". He recalled how in 2010, a senior US official, Johnnie Carson, addressing an audience in Lagos, described China as "a very aggressive and pernicious economic competitor with no morals", and asked if the western world could actually claim to have the moral high ground for passing this kind of judgement against the Chinese in Africa given its own egoistic dispositions to Africa and Africans? His answer was a categorical "No"! According to him, the entire scenario amounts to no more than "a case of a jealous lover castigating and casting aspersions on a rival". ${ }^{16}$

He accused the western world of rapacious colonisation and therefore wondered why that same part of the world should accuse other nations of colonial interests. He was particularly irked by the fact that some Africans were joining the western media in demonising the Chinese. Of particularly interest to him in this respect was the case of Jacob Zuma, the President of South Africa, and Lamido Sanusi, the former Governor of The Central Bank of Nigeria, who have joined the bandwagon of those criticising the Chinese. He argued that the two of them have only been attacking China "without substantiating what it is that China has done that smacks of re-colonization". He noted further that:

We value the judgment of these leaders as we should and will support their assertions without any reservations if they are valid and are legitimate criticism against China or anyone else because we know that their hearts are in the right place. They, more than anyone, have earned the moral right to plead our cause. That said, our leaders cannot be perceived as gigantic amplifying mouthpieces raising the volume of apparent false whispers that smack of the West's assertions and subservient heteronomy.... Our leaders should resist 
the bait and not become pawns in the West's power play with China. The West has done wrong by us and do not have any inclination to change. They have forfeited any moral right to plead our cause and this latest effort is not sincere but rather an avaricious vicious self-interest clothed in hypocritical outrage.... Over five hundred years, of interaction with Africa has produced nothing but misery for Africans. It is a little bit self-serving and ironic to try and play the protector since all the West has ever done is keep Africa then and now perpetually underdeveloped.... A legacy of rapacious colonization left Africa bereft of any capital to make the leap to modernization and whether we realize it or not, we are still hampered by the effects of colonialism. You cannot tell a man to pull himself up by his bootstraps after you have stolen his boots and he lacks the straps to pull himself up with.... Now that China is making an effort to provide the bootstraps, the West will, and is doing all that it can to scuttle this because it is not in their best interest to see Africa develop.... If Africa is slipping from the orbit of the West, the West has itself to blame. They had the chance and obligation to do right by Africa for our mutual benefit but they chose not to. Not only have they not made any meaningful effort to invest in Africa but have lately embarked on a most insidious foreign policy, a campaign to besmirch Africa and Africans in the eyes of the world. ${ }^{17}$

To buttress his position, Iheke called attention to how the US, which benefited from the Marshall Plan that guaranteed a ready market for American goods and services and greater prosperity for all, was not ready in the 1960s to support same for Africa. The US preferred to give Africa foreign aid that would make it a beggar continent. That is what Africa is today. He accused the farmers in the western world of impoverishing African farmers through their governments in order to open their markets to African producers. He asked:

With all the wealth they took out of Africa, what will it cost them to help build power generation plants for example across Africa knowing full well that Africa cannot develop when all the electricity generated in Sub-Saharan Africa amounts to only 150 billion KWh/year excluding South Africa and is less than one third of the electricity produced in France alone at 510 billion $\mathrm{KWh} /$ year.... Where is the fairness.... ${ }^{18}$

Iheke argued that it would be immoral for anybody to accuse the Chinese of helping to fill the deliberate gaps in western business strategies in Africa. His position is that if the West is not treating Africa with dignity others should not be prevented from doing so.

The argument above is that for now China's interaction with Africa indicates that it is a transformative force offering an alternative model of development for the continent in the sense that this is the first time since the end of European colonialism that the continent would not be treated as a charity case but as a strategic business partner by the outside world. China literally deregulates Africa's economy by giving the people choices. China's involvement in African development can be seen as an opportunity to foster links between people and as a new paradigm shift away from the entrenched world order. This is good for Africa. The Chinese' scramble for Africa also provides the continent a recovery mechanism in an age of global economic meltdown when the investment of the Western world is shrinking 
in Africa largely because these countries have their own internal problems and the conditions tied to their foreign aids are sometimes not supportive of sustainable development goals.

Africa's relationship with China is endorsed by the African Union and the African Development Bank. For example, in 2010 Maxwell Mkwezalamba, the All's economic chief, made bold to advise that the African Union should turn in the direction of China for development support because the conditions and checks often stalled the flow of funds from western nations and the World Bank. As he said,

"For Africa's development and integration we have depended on the Western world - we cannot continue to proceed like this.... We need to diversify our partners that we work with and hence for us, working with China is something that we have welcomed."

He argued that when the likes of the World Bank agree on any facility for Africa, they impose "huge conditions" and the "resources tend to come very slowly. They tell you that you are going to get $\$ 100$ million today but then you don't get the $\$ 100$ million until after maybe two years because the whole question of processing the loan takes a long time.... By getting support from China and other countries we strengthen our position". ${ }^{19}$ Indeed, the Chinese support for Africa is widely believed to have positive effects on African economies. The opinion of Meyersson, Miquel, and Qian on this is very instructive:

We find that exporting NR (natural resources) to China has positive effects on short term economic growth, capital formation and the development of value added industries. A $1 \%$ increase in exports to China increases one year GDP growth by $0.2 \%$ and three-year growth by $0.7 \%$. The economic benefits are much larger than that obtained from exporting to the U.S. or India, another rapidly growing democracy. For human rights, our results show that exporting NR to China has an adverse effect. However, it is similar to the effect of exporting NR to the U.S., a rich and powerful democracy. ${ }^{20}$

The situation could also be presented in libertarian terms as observed by Mahamat Hassan Abakar, a lawyer in Chad, a former French colony in central Africa when he said "Let the Chinese come.... What Africa needs is investment. It needs partners. All of these years we have been tied to France. Look what it has brought us." 21

There is no doubting the fact that the influx of China's cheap and user-friendly phones into Africa has significantly improved not just communication butalso e-governance in the continent. The Chinese are also ready to invest in unconventional terrains where western companies are most likely to exercise restraint. In the process, they expand the opportunity for job creation in different parts of Africa. Not even the elite class perceives the Chinese presence in Africa to be as problematic as presented in the media. As Kurlantzick observed:

African elites and publics have welcomed China's presence: Programme on International Policy Attitudes polls show, for example, that 62 percent of South Africans believe China is having a positive influence on the world. Some African elites perceive China as different from Western donors 
and investors; Beijing is not linked to the neoliberal economic model and its past structural adjustment programs. Even the head of the African Development Bank has announced that, "We can learn from (the Chinese) how... to move from low to medium income status",22

In other words, many think Africans need the Chinese as the latter needs Africa. The people can see the infrastructures: roads and industries built by the Chinese. They can see the power plant projects funded by the Chinese. They are provided employment opportunities by the Chinese. ${ }^{23}$ Against this background, the question that should engage our attention revolves around how Africans can make the best of the presence of the Chinese. The on-going demonization project is better handled by Africans as an agenda-setting opportunity in whatevernegotiation they must have with the Chinese.

The current "rogue state" status of China in Africa does not indicate that the issues raised can be solved in a jiffy. Arecent report shows that as the likes of the US continue tOo expose the shortcomings of China in Africa and other parts of the developing nations, it would continue to be shielded by some powerful members of the UN's Rights Council, namely Russia, Pakistan, Cuba and Saudi Arabia. On account of its dismal performance, the UN Watch recently described the UN Rights Council as "Foxes guarding the chickens". ${ }^{24}$

The last point we have to make here is that the concerns of the western world about Chinese presence in Africa are based on two misleading assumptions. The first is that Africans need a paternalistic entity to advise it about what is good or bad for it. The second is that Africans accepts all proposals coming from China. A number of cases exist to prove these positions wrong.

The formation of the Forum on China-Africa Co-operation (FOCAC) is evidence that Africans have the ability to forge international connections and partnerships beyond what was imposed on them by development partners in the past. Agood example to illustrate this can be taken from the Democratic Republic of Congo where a US\$ 3 billion "infrastructure for resources" loan was rejected in favour of an alternative offered by the International Monetary Fund. This shows that the government knows what is best for it. ${ }^{25}$ Indeed many African governments now see the presence of China in Africa as an opportunity to secure better economic gains from both China and traditional patterns such as the EU. ${ }^{26}$

The other point that has to be made is that individual African countries deal with China according to their respective national interests. There is no universal African strategy for dealing with the country. On the other hand, it must also hold that not all the Chinese groups that African countries deal with have a direct relationship with the Chinese state apparatus.

It is interesting to note that as western nations criticise China in Africa, they have developed their own way-of working with the country. In 1993, the US tried to tie the renewal of China's "Most Favored Nation" status for international trade to some human rights conditionalities. This pressure tactics had to be dropped a year later when progress could not be made in that direction. The attempt also made by the US to censure China at the United Nations Human Rights Commission was nullified when China successfully rallied support 
around itself. Both the US and EU now dialogue with the Chinese. ${ }^{27}$ Western business organisations are also cautious of the ways they relate with China when it comes to issues of respect for human rights. Commenting on this, Kampf observed that:

Powerful international businesses have capitulated to China's demands to ensure unfettered access to its booming economy. Last year, Yahoo! And Microsoft's MSN agreed to censor specific content on their Web sites, and Yahoo! passed user information to the government. Google, whose official motto is "Don't be evil," agreed to filter the content of searches on "sensitive" subjects such as Tibet, democracy and human rights for Chinese Internet users. ${ }^{28}$

The World Bank has had its own tough brush with China and it had to compromise some of its standards in the process. The attempt by the Bank in 2007 to further link its lending to a country's governance and corruption record was opposed by China which threatened to stop borrowing from the Bank. The position of China was that this kind of step would intrude into a country's internal affairs. Of course, making loans to the developing world is the main mandate of the Bank. So the Bank was brought under pressure to water down its anticorruption strategy at least to accommodate the interests of China. ${ }^{29}$ -

The point being made by circumlocution in this paper is that China is not a soft nut to crack. As the other nations of the world seek how to engage it, Africa should not be carried away by the ongoing demonization project against the country. What is needed now is for Africans to learn to demand more from the Chinese as they are the ones holding the resource card desperately needed by the Chinese. Africa must set standards for the Chinese companies. Corporate social responsibility must be demanded from them. Local industries that could be threatened by the presence of the Chinese should be adequately protected.

\section{Conclusion}

This paper shows that African governments turn in the direction of China because they are tired of the authoritarian influences of western powers in Africa. On the other hand, the grassroots consider the economic models of the western world to be pro-rich and not pro-poor. By having access to cheap Chinese products, these people that have long been abandoned by their governments and global corporate bodies are now regaining their basic humanity. On balance, Africans consider the Chinese business strategies to be more morally acceptable than those of the western world and are therefore not persuaded by any criticism of China in Africa. If the west wants better deals with Africa, it is recommended that it has to learn lessons from how the Chinese do business. The Chinese must also learn from the expanding failure of the west in Africa.

In other words, the fate of China in Africa will be determined not by what the western media say. The decision has to be made by Africans themselves who are the victims of whatever is said to be wrong with how the Chinese do business in Africa. Hearts and minds are won in two possible ways: through dogmatic beliefs and through persuasive experiences. Both African leaders and peoples work with the Chinese for mutual benefits; the two sides gain from the process. What seems to be propelling Africans is encapsulated in a Yoruba adage that says that "If you rest on a tree and it fails to support you, the same tree cannot kill you 
if it falls on you". The way the western world has been dealing with Africa in the past now accounts for why Africans are looking in the direction of China for survival.

If the western world wants a change in the attitude of Africans to the Chinese, it must offer something better than the Chinese are offering. No amount of criticism of China would change the attitude and behaviour of Africans towards China. But both China and African governments must learn from the unfolding scenarios. China must now face the reality that it is under suspicion of coming to pursue a colonialist agenda in Africa. China should read its lessons from the decolonisation of Africa very carefully and realise that the people are even now wiser.

For now, Africans are too poor to appreciate the human rights debate in the western world. Only well-fed people would consider human rights activism on the hierarchy of human needs. But as things get better for Africans, they would definitely begin to ask human rights questions. In this context, Chinese companies glued to rogue governments might soon begin to face problems as the African peoples start to get rid of these regimes as witnessed in some parts of North Africa. As these governments go, any foreign powers that work with them will also go. This has already happened to China in Libya, whether rightly or wrongly. Hence, it would be wise now for China to start to reflect on how to support human rights work in Africa.

\section{Footnotes}

${ }^{1}$ Erik Meyersson, Gerard P. Miquel, and Nancy Qian, "The rise of China and the natural resource curse in Africa", Brown University, Harvard Academy, April 7, 2008. http:// siteresources.worldbank.org/INTMACRO/Resources/ June 5 \& 62008 MG Conference PAPERQIAN.pdf.

${ }^{2}$ Bridgette Liu and Richard Stocken, "Africa: Why Chinese Companies Are Successful in Africa", All Africa, 4 January 2012, http:// allafrica.com/stories/201201040375.html.

${ }^{3}$ Anver Versi, "China, Japan square up over Africa”, African Business, February 2014 p. 13.

${ }^{4}$ C. Alessi and S. Hanson, Expanding China-Africa oil ties - council on foreign relations, 9557, 2012,pp.1-6.

${ }^{5}$ Ian Taylor, “China’s Oil Diplomacy.” International Affairs, 82:2006, 937-959.

${ }^{6}$ P. Van Dijk, The new presence of China in Africa, Amsterdam University Press, 2009.

${ }^{7}$ Jason Groves, "Cameron warns Africans over the 'Chinese invasion' as they pour billions into continent”, MailOnline, 19 July 2011 http:/www.dailymail.co.uk/news/article-2016677/ Cameron-warns-Africans-Chinese-invasion-pour-billions-continent.html.

${ }^{8}$ Robert I. Rotberg, China into Africa: Trade, Aid and Influence, Washington, D.C. and Cambridge, MA, 2008 pp. 21-37. 
${ }^{9}$ Stephanie Hanson, "China, Africa, and Oil", Backgrounder, Council on Foreign Relations, http:/ L www.cfr.org/publications/9557/, accessed 11 December 2009.

${ }^{10}$ William Walli, “Africa warned of China exploitation”, March 222013 , http://www.bdlive.co.za/world/africa/2013/03/13/africa-warned- of-china-exploitation.

${ }^{11}$ Paul Collier, The bottom billion: Why the Poorest Countries Are Failing and What Can Be Done About It, Oxford University Press, 2008.

${ }^{12}$ Cited from ADF Staff, "Mobile unit brings the net to rural villages", Africa Defense Forum, Volume 5 Quarter 1,2013 p. 21.

${ }^{13}$ Cited from ADF Staff, "Mobile unit brings the net to rural villages", Africa Defense Forum, Volume 5 Quarter 1, 2013 p. 21. Also see "Facebook and other social media sites struggle to control extremist activity"Africa Defense Forum, Volume 5 Quarter 1,2013 p. 23-25.

${ }^{14}$ Kunle Azeez, "Nigeria's active phone lines hit 121.8 milli9n", National Mirror, Jan 28,2014.

${ }^{15}$ Anthony Mulowa, "Africa: We've Moral Obligation Towards Africa - China”, Times of Zambia, 4 June 2013, http://allafrica.com/stories/201306050391.html.

${ }^{16}$ Chima Theke, "Has the West Fortified the Moral Right to Plead Africa's Cause?", Sahara Reporters, Jul, $202013 \mathrm{http} / /$ saharareporters.com/article/has-west-fortified-moral-rightplead-africa $\% \mathrm{E} 2 \% 80 \% 99$ s-cause-chima-iheke-phd.

${ }^{17}$ Chima Theke, "Has the West Fortified the Moral Right to Plead Africa's Cause?", Sahara Reporters, Jul, $202013 \mathrm{http} / /$ saharareporters.com/article/has-west-fortified-moral-rightplead-africa $\% \mathrm{E} 2 \% 80 \% 99$ s-cause-chima-iheke-phd.

${ }^{18}$ Chima Theke, "Has the West Fortified the Moral Right to Plead Africa's Cause?" Sahara Reporters, Jul, 202013 http://saharareporters.com/article/has-west-fortified-moral-rightplead africa\%E2\% $\% 0 \% 99$ s-cause-chima-iheke-phd.

${ }^{19}$ Maxwell Nkwezalamba, "China gets massive endorsement from the African Union, NTA Newstime Africa, July 25 2010, http://www.newstimeafrica.com/archives/13409.

${ }^{20}$ Erik Meyersson, Gerard P. Miquel, and Nancy Qian, "The rise of China and the natural resource curse in Africa", Brown University, Harvard Academy, April 7, 2008 http:// siteresources.worldbank.org/INTMACRO/Resources June 5 \& 62008 MG ConferencePAPERQIAN.pdf pp. 19-20.

${ }^{21} \mathrm{New}$ York Times "New power in Africa: China's Trade in Africa Carries a Price Tag" August 21,2007 .

22 Joshua Kurlantzick, "Beijing's Safari: China's move into Africa and its implications for aid, development and governance", Policy utlook, Washington DC: Carnegie Endowment for International Peace, 2006 p. 3.

${ }^{23}$ Commenting on this issue Yang Guang, the Director of the Institute for West Asian and African Studies at the Chinese Academy of Social Sciences noted in an interview in November 28, 2007 that in 2006 the total number of Chinese people in Africa was 80,000 but the number of jobs created for local people was about 70,000. 
See Stephanie Hanson, "Guang: Chine and the United States 'do not have strategic conflicts' in Africa, Council on Foreign Relations, November 28,2007 http://www.crr.org/publication/14870/ guang.html, accessed on 11 December 2009.

${ }^{24}$ Globalpost, "Rights group: New report shows UN rights council shielding worstabusers, "Foxes guarding the chickens", http://www.globalpost.com/webblog/diplomacy/rights-group-new-reportshows-un-rights.

${ }^{25}$ B. Jopson \& W. Wallis, 'Congo Cuts Back Aid Deal with China', Financial Times, (12 November, 2009). See: www.ft.com/cms/s/0/dd360fca-cf2b-1 Ide-8a4b-00144feabdc0.html. (Accessed 13 November, 2009).

${ }^{26}$ C. Alden, 'Leveraging the Dragon: Toward "An Africa That Can Say No"”, Yale Global Online, (1 March, 2005). See: http://yaleglobal.yale.edu/content/leveraging-dragon-toward-africa-can-sayno. (Accessed 22 December, 2009). Also see H.G. Broadman, Africa's Silk Road: China and India's new Economic Frontier, (Washington, D.C.: World Bank, 2007), pp. 33-34.

${ }^{27}$ David Kampf, "China's rise and the implications for international human rights", China Rights Forum, Number 1,2007 p. 46.

${ }^{28}$ Ibid.

${ }^{29}$ Richard Behar, "World Bank anticorruption drive blunted as China threatens to halt loans", Fox News.Com, http://www.foxnews.com/printer friendly story/0,3566,261290,00.html, accessed 11 December 2009. 